erson Narrati-

kiokoulutuksen

reates Its Mea$1: 1,35-64$.

ider. Teoksessa

. Calin-Andrei $159-164$.

or, and Narra-

m. David Her-

läinen formalisKS. 266-281.
Kai Mikkonen

\section{Keskustelun jatkoksi: kertomuksesta ja elämästä}

Eeva Salonius käytti Jamaica Kincaidin romaania Mr. Potter tarkastelevan puheenvuoronsa (Avain 3-4/05) lähtökohtana aiemmin tässä lehdessä julkaistua esseetäni (1/05). On hienoa, että tekstini löysi käyttöä. Valitettavasti näytän kuitenkin epäonnistuneen yrityksessä tasapainotella kertomuksen kiistämättömän merkityksen ja universaaliuden sekä sen yhtä lailla väistämättömien rajojen välillä. Salonius yhdistää pohdintani väitteeseen, että "vain kertomuksen kautta ymmärrämme tätä maailmaa". Tähän on vaikea yhtyä ja vielä vaikeampaa sitä olisi osoittaa toteen. Kertomus on varmasti aktiivisen merkityksenannon muoto, mutta tuntuu kuin Salonius assosioisi tässä vielä hurjemmalla tavalla kuin jotkin mainitsemani kerrontaa pohtivat sosiaalitieteilijät, filosofit ja psykologit. Ikään kuin kaikki todellisuuden esittäminen olisi kertomista tai kertomus olisi sama asia kuin kieli, jolloin voidaan myös väittää, että ihmisellä ei voisi olla näkökulmaa elämäänsä ja asioihin ilman kertomusta.

Kertomusta ei ole kuitenkaan syytä samastaa kieleen, "näkökulmaan" tai kaikkeen merkityksenantoon. Varsinaisten kertomusten ulkopuolella eivät ole pelkästään useimmat modernit runot tai kuvataide. Myös niin arkipäiväiset asiat kuin käsitteellinen ja kielikuvallinen ajattelu, looginen päättely ja ympäristön havainnointi pärjäävät ilman kertomusta (vaikka nekin voivat saada kertomuksen muodon). Kertomuksen ja ihmiselämän vertaaminen toisiinsa on myös kyseenalaista, ellei naiivia, jos ajatellaan ihmiselämän jotenkin luonnollisesti samastuvan juonen tapaiseen elämänkaareen. Ei siis ole ihme, että viime vuosien pyrkimys tehdä kertomuksesta identiteetin rakenne tai ihmismielen peruselementti, on johtanut tervetulleisiin vastareaktioihin.

Näistä reaktioista toin esseessäni esille filosofi Peter Lamarquen artikkelin (2004). Vastaavalla tavalla kriittinen on filosofi Galen Strawson, jonka kirjoitusta "Against Narrative" (2004) on levitetty myös suomalaisella kertonet/kertomus -sähköpostilistalla. Strawson liittää yhteiskuntatieteilijöiden, kuten Jerry Brunerin ja Oliver Sacksin, tai filosofien, kuten Charles Taylorin ja Alasdair MacIntyren, vaikutusvaltaiset kertomusteoriat tiettyihin psykologisiin ja eettisiin oletuksiin, joiden yleispätevyyttä on vaikeaa tai mahdotonta todistaa. Strawson kyseenalaistaa ajatuksen, että elämän kokeminen kokonaisuutena, tai hyvä elämä yleensä, vaatisi kertomuksia. Valitettavasti hän samalla sivuuttaa kertomusten tärkeän tehtävän kognitiossa, kommunikaatiossa ja tiedonväli- 
tyksessä, mutta jääkööt kiistan yksityiskohdat sivuun tässä. Otan vain esiin Strawsonin ajatuksen siitä, että on olemassa syvällisessä mielessä ei-kertovia tai episodisesti asioita kokevia ihmisiä, jotka eivät ajattele elämäänsä kronologisesti, eli menneisyyttä menneisyytenä, vaan menneisyyttä osana nykyhetkeä. Kertomustaan elävän tai elämäänsä kertomuksilla merkittäväksi tekevän ihmisen vaihtoehdoksi ei tarvitse siten olettaa "pirstoutunutta identiteettiä" Saloniuksen tavoin.

Historiallinen näkökulma, siis ajalliset muutokset huomioon ottava tarkastelutapa, ei ole riippuvainen kertomuksesta, sillä onhan historiankirjoituksella myös muita muotoja käytettävissään. Kausaalisen päättelyn ei myöskään tarvitse olla kertomuksen omaista, vaikka tapahtumien kausaaliset suhteet ovat useimpien kerronnan teoreetikkojen mukaan keskeisiä kertomuksen elementtejä.

Saloniuksen tapa yhdistää kertomus "ehjään identiteettiin" tuo ehkä tahattomasti mieleen tietyt minäpsykologian muodot, jotka korostavat minuuden eheyttämistä kertomusten avulla. En halua väheksyä kertomuksen lukuisia terapeuttisia mahdollisuuksia enkä myöskään postkolonialistisen traumatarinan erityislaatuisuutta, mutta jos identiteetin eheys tarkoittaa jonkinlaisen valmiin ja kontrolloidun minuuden ihannetta, liikutaan varmasti heikoilla jäillä.

Prosessinomaisuus kuuluu kertomuksiin niin olennaisesti, että yhtä lailla ideaali eheästä, valmiista minuudesta kuin kuvaus sosiaalisesta utopiasta edustavat jonkinasteista kertomuksen kuolemaa. Valmiille asialle ei enää tapahdu mitään, eikä siitä siis enää kannata kertoakaan. Toisaalta oletus siitä, että traumakokemus, tuska tai syrjinnän tunne olisivat rakenteeltaan kertomuksen muotoisia, on eettisesti kyseenalainen ellei absurdi päätelmä. Yhdyn aiemmin lainaamani Matti Hyvärisen näkemykseen, jossa hän toteaa että "kuuntelemisen etiikka suorastaan huutaa sen puolesta, että kertomuksella on ulkopuoli" (2005). Assosiaatio "ehjän identiteetin" ja kertomuksen välillä ei myöskään voi olla peräisin Saloniuksen käyttämiltä auktoriteeteilta kuten Bhabha ja Said, joille se olisi ongelmallinen ajatus. Tutkivathan Bhabha ja Said nimenomaan (post)kolonialistisen historian ja todellisuuden esittämistä (esimerkiksi kertomuksin) ja tapoja käyttää esityksiä vallan palveluksessa.

Esseessäni viittasin lyhyesti siihen, että uskonnollisessa kokemuksessa voidaan löytää vastineita tekijöille ja kertojille. Tällä tarkoitin lähinnä sitä, että lukuisille ihmisille on arkipäiväistä ajatella Jumalaa voimana, joka on vastuussa maailman tekemisestä ja joka toimii jonkinlaisessa elämän suuren kertojan roolissa. Voinee joku myös ajatella olevansa Jumalan luoma henkilö(hahmo). Tämä oli kuitenkin vain sivuhuomautus. Vertaus on ilmeisen ontuva. En kuitenkaan osaa nähdä historiaa elämän "arkipäiväisenä" kertojana sillä tavoin kuin Salonius olettaa. Historian kertojat ovat aina sen tekijöitä. Historiankirjoituksessa ei yleensä ole tarpeellista erottaa tekijää ja kertojaa toisistaan toisin kuin nykykirjallisuudessa. 
in Strawsonin disesti asioita eisyyttä mentai elämääne siten olettaa tarkastclutaa myös muita kertomuksen tan teoreetik-

i tahattomaseheyttämistä sia mahdollitta, mutta jos iden ihannet-

lailla ideaali vat jonkinaseikä siitä siis ska tai syrjinsyseenalainen mykseen, josa, että kertonuksen välillä cuten Bhabha nimenomaan rtomuksin) ja

voidaan löysille ihmisille ekemisestä ja myös ajatella uhuomautus. "arkipäiväisena sen tekijöijjaa toisistaan
Kommentissaan Salonius on toki looginen itselleen jatkaessaan levottomien assosiaatioiden sarjaa niin, että samastaa myös historiankirjoituksen ja fiktion. Saloniuksen tavoin voidaan varmasti perustellusti väittää, että historiankirjoiruksella on aina näkökulma, että se on usein kertomuksen muodossa tai että se on rekonstruktio menneestä, joka on avoin tulkinnalle. Tämä ei kuitenkaan tee historiasta fiktiota. Niin voidaan väittää ainoastaan, jos fiktio mielletään hyvin laajasti ja hahmottomasti, jolloin se samastuu kaikkeen kertomiseen, esittämiseen, merkityksenantoon tai kieleen yleensä. Kirjallisuudentutkijalle ei kuitenkaan ole kovin hyödyllistä ymmärtää alan keskeistä käsitettä näin sekavasti. Toiset kertomukset kun ovat fiktiota ja toiset eivät.

Historiankirjoituksella ja fiktiolla on monista yhtymäkohdista ja loputtomista kosketuskohdista huolimatta myös erilaisia kriteerejä ja rajoituksia. Näistä tärkeimpiä on vaatimus historiankirjoituksen viittaavuudesta todellisuuteen. Fiktion kirjoittajan ei ole välttämätöntä seistä kertojansa takana eikä hän ole historian kirjoittajan tavoin vastuussa vaikkapa teoksessaan esitetyistä rasistisista kannoista. Tekijän ja kertojan eron ongelmaa postkolonialistisen kirjallisuudentutkimuksen kannalta on pohtinut terävästi esimerkiksi Nicholas Harrison (2003, 59-60). Kysymys fiktion ja historiankirjoituksen suhteesta, mukaan lukien Jamaica Kincaidin suhde romaaninsa osittain omaelämäkerralliseen kerrojaan, on laajempi ja kimurantimpi kuin Salonius antaa olettaa. Esimerkiksi kun Kincaidin syntymänimen omaava kertoja Elaine toteaa tehneensä isänsä henkilökuvasta puhtaasti oman näkemyksensä mukaisen, "fiktionalisoi" hän silloin elämäkertaa eikä vain vastusta tiettyä historiakäsitystä. Ei ole ehkä olennaista tai edes mahdollista arvioida, pitäisikö teosta tästä syystä lukea nimenomaan fiktiona, mutta joka tapauksessa tietty etäännyttäminen kirjailijan ja kertojan nimien välillä sekä näkökulman korostunut subjektiivisuus vaikuttavat myös itse teoksen tulkintaan. Tässä yhteydessä kannattaa mainita juuri loppuun saattamamme suomennostyö tärkeästä fiktion ja historiankirjoituksen suhdetta käsittelevästä tietokirjasta, Dorrit Cohnin Fiktion mielestä (Gaudeamus 2006). Kiitän kommenteista ja mahdollisuudesta jatkaa keskustelua.

\section{Lähteet}

harrison, nicholas 2003: Postcolonial Criticism: History, Theory and the Work of Fiction. Cambridge: Polity Press.

HYVÄRINEN, MATTI 2005: Kertomuksen tuolla puolen. Tarkkoja siirtoja. Erkki Vainikkalan jublakirja. http://tuki.hum.jyu.fil-julkaisu/johdanto.html (11.2.2006). Lamarque, PeTer 2004: On Not Expecting Too Much from Narrative. Mind \& Language 19.4 (September 2004): 393-408. STrRaWson, galen 2004: Against Narrative. Times Literary Supplement (October 15, 2004).http://www.rdg.ac.uk/AcaDepts/ld/Philos/gjs/antls.htm (11.2.2006). 